Article

\title{
Community Participation in Nature Conservation: The Chinese Experience and Its Implication to National Park Management
}

\author{
Siyuan $\mathrm{He}^{1}{ }^{1}$, Lingfan Yang $^{2}$ and Qingwen Min ${ }^{1,3, *}$ \\ 1 Institute of Geographic Sciences and Natural Resources Research, Chinese Academy of Sciences, \\ Beijing 100101, China; hesy@igsnrr.ac.cn \\ 2 School of Environment, Beijing Normal University, Beijing 100875, China; yanglf0521@foxmail.com \\ 3 University of Chinese Academy of Sciences, Beijing 100049, China \\ * Correspondence: minqw@igsnrr.ac.cn
}

Received: 8 April 2020; Accepted: 9 June 2020; Published: 11 June 2020

\begin{abstract}
Rural communities are taking active roles in conservation. However, the basic modes and content of community participatory approach are seldom summarised or reflected on in China, leaving the use of terms confused and their links to practice disconnected. By reviewing the literature, we traced back to the protected area-community relations from the perspective of features of rural communities, namely knowledge accumulation, social bond, collective actions, and risk-aversion, and reflected on changing roles of community conservation through recognition of these features. Combining case studies and our own research experience, we focused on the de facto practices behind the somewhat casual use of several terms and re-classified community participation in conservation to three modes of community participatory management, community co-management, and community dominant management, along a continuum in which, from low to high level, conservation is more a means rather than an end for the community to be empowered for their own resource management. We argued that the success of community participation must ensure stable and flexible land tenure so that the right to benefit can be guaranteed, and the collective action in managing resources can be achieved by empowerment. In practice, further institutional changes of improvement in the legislation and optimisation in benefit sharing and compensation are needed to promote community participation in a broader social participation context.
\end{abstract}

Keywords: community participation; empowerment; protected areas (PAs); conservation; land tenure; collective action; national park

\section{Introduction}

The role of the community in conservation is gaining growing concern in the global conservation cause [1]. With more ecologically valuable areas designated as protected areas (PAs), conflicts between the resource use of local people and conservation become prominent. Appropriate approaches to balance the public need for sustaining biodiversity and natural heritage and private need for basic livelihood and culture maintenance are always under discussion and practice around the world $[2,3]$. China is also seeking ways to coordinate community livelihood and conservation under its current process of setting up national parks and the reforming of protected-area systems [4].

Research into the social-ecological system has shed light on the provision of these approaches. The social-ecological system framework indicates that the rural community interacts with nature through resource management [5]. The social and ecological systems are closely interlinked because natural resources are the basis for the social-economic development as well as an important component 
of biodiversity and ecosystems. Thus, three major approaches are widely used to resolve the conflict between resource use and nature conservation [6]. The first is the compulsory conservation policies, laws, and administrative orders which are efficient in the short-term, but have cost local communities development opportunities and can deepen the conflict. The second is regulating resource use through a self-disciplined way by social norms and regulations. It is not compulsory, and dynamic in a changing social context so the effect may be unstable and limited. The third one is an integrated conservation approach that considers natural resource use as part of conservation, and the community an essential power in conservation activities. The former two approaches can be integrated to the third to maximize conservation effects with the least damage to communities' benefit. Therefore, it is necessary for conservation to consider the use of natural resources from a systematic view by linking the natural resource use of the local community to conservation [7]. This viewpoint expands the view of conservation as an end to conservation as a means for a sustainable and fair natural resource use and benefit sharing from empowering the community.

Therefore, it is not uncommon that community participation has been introduced to protected area (PA) management in which community people's natural resource use and management are important $[8,9]$. The earlier discourse of positioning local communities to an opposite side of conservation and of the necessity of top-down government compulsory management has also gradually shifted to the idea that an effective public participation can ensure the consistency and continuity of information and promote the legitimacy and rationality of decision making in conservation [10]. Actually, from the perspective of park-people relations, if the protected area could bring more benefits and reduce the cost to the local people, it can have more local support and fewer conflicts [11,12].

Globally, growing attention has been paid to the sharing of responsibility and rights among stakeholders in the protected area management concerning the complexity of land tenure [13]. Communities have been taking part in conservation since the 1960s. Some approaches emerged and have been gradually adopted. Community-based Nature Resource Management (CBNRM) as a term and approach emerged in the early 1990s, referring to the collective use and management of natural resources in rural areas by a group of people with a self-defined, distinct identity, using communally owned facilities [14]. This approach is applied in many conservation projects through local sustainable natural resource use. Integrated Conservation and Development Programme (ICDP) was mainstreamed in 1992 [15] and grew to a standard management approach for international non-governmental organisations (NGOs) and development agencies, such as participatory forestry by the Food and Agriculture Organization of the United Nations (FAO) [16]. Community-based conservation (CBC) became notable in 1982 at the World National Parks Congress [17] and was considered to have several distinct phases [18]. ICDPs were somewhat interchangeable with the early stage of CBC in the 1980s, while as many of them rarely concerned conservation and development at the same time, later $\mathrm{CBC}$ went further by trying to establish a direct linkage between conservation and local benefit [19]. Thus, the CBC initiatives aimed at protecting biodiversity while promoting local development $[7,20]$ with main strategies of (i) integrating conservation and livelihood goals, (ii) providing economic and development benefits in return for conservation, and (iii) providing communities control over their natural resources [21]. Global experience both in developing and developed countries has confirmed that community participation in protected area management can be adapted to different social-ecological conditions with different conservation targets [3,6,7]. Research has also revealed that many factors can impact the success of community participation, such as formulation and implementation of laws and regulation, acceptance of local knowledge and development demand, provision of social welfare, etc. [13]. In general, community participation allows the local people to contribute to decision making in order to solve the problems they think as essential and relevant and help to control the solution. 
China is also active in exploring community participatory approaches in protected area management based on worldwide experience and adapting to its ongoing social context since the early 1990s [22]. International and national NGOs are active in working with government to absorb communities into existing management of government designated protected areas, and to seek expansion of the protected-area system to absorb sacred sites and nature mini-reserves, which are usually initiated by communities or local conservation groups $[6,23,24]$. Therefore, community participation in China may not be a new idea in conservation, but it is definitely becoming more institutionalized as a counterpart to top-down governance.

Under global conservation initiatives, many projects were launched around China, however, the use of relevant terms referring to certain participatory practice is somewhat random and even not matching practice in the real world. Furthermore, these terms, as well as those concrete forms of practice (such as trusted management), were not clearly summarised based on theory to an institutional level for governance improvement or so. Admittedly, with more than half a century's conservation practice, the role of community continues to change as manifested by loads of cases to impact conservation outcomes. It is thus necessary and also urgent to draw some lessons and enlightenment by identifying the fundamental participation modes. Recently, some scholars tried to identify modes from limited cases [24]. However, it may have also added confusion by juxtaposing cases representing different scales of practices and approaches together as if they belong to the same scale, such as juxtaposing Protected Area Friendly System, which is basically a production model with criteria and certification procedures for products from protected areas, and Community Participatory Management.

Therefore, the objectives of this study were to: (1) Identify communities' role in nature conservation in China; (2) clarify the confusion in the use of terms of community-involved conservation in the Chinese context; and (3) propose institutionalised suggestions to China's national park management. The core of the study is to achieve a concise classification of theoretical participation modes, which was abstracted from, but can also guide, on-the-ground practices in China. These objectives were reached mainly through a literature review and the authors' own observation and research experience with case studies. In the Results, the article presents a concise review of the community's role in the protected area management in China by tracing back to the relations of rural communities and protected areas from the perspective of community features. It then clarifies randomly used terms, and matches them to theory so as to propose participation modes, namely community participatory conservation, community co-management conservation, and community dominant conservation, with key features identified by an explanation of typical practices under several terms. The article further identified key factors impacting the success of community participation and proposed suggestions for better facilitating community participation in the management of national parks accordingly.

\section{Materials and Methods}

This research was conducted mainly in the peer-reviewed Chinese scientific literature, consisting of three phases. Being aware of the various natures of community involvement in conservation and the naming of projects, the first phase was geared at generating a master list of names of the community-involved conservation models for further review. Hence, we consulted experts in terms of community-involved conservation activities in theory and practice, these experts including scholars in ecology and conservation, NGOs' project officers, and protected area management committee members. Those identified concepts include community-based conservation (She Qu Bao Hu), participatory management (Can Yu Shi Guan Li), joint management (Gong Tong Guan Li), community co-management or condominium (She Qu Gong Guan), cooperating management (He Zuo Guan Li), community participation/participatory (She Qu Can Yu), as well as "stewardship" (Xie Yi Bao Hu), “trusted management" (Wei Tuo Guan Li), and "mini reserve" (Zi Ran Bao Hu Xiao Qu). 
The second phase consisted of retrieving journal articles according to the master list. Hence, we performed a literature search query on the CNKI (China National Knowledge Infrastructure) database on the Institute of Geographical Sciences and Natural Resources Research on 11 December 2018. The above-mentioned nine concepts were independently searched in the options Article Title and Keywords to retrieve journal articles, combined with searching of "nature conservation" and/or "community" in Abstract if necessary, to make sure the co-appearance of the meaning of community and the conservation management practice. This resulted in a sample of 64 articles ranging from 1992 to 2018. About ten papers were dropped because the main focus was non-Chinese cases. The remaining 50 articles, as well as several relevant books, were used for analysis in the third phase. Within the 50 articles, about $20 \%$ focused on the theories and general progress of the community-involved conservation, and $80 \%$ were case studies to practices of the eight different names focusing on multiple aspects of community participation, including planning, incentive mechanism, limiting factors, etc., as well as some comparative studies.

The third phase consisted of scaling up community participatory modes according to case studies in articles and books, as well as the authors' research experience. The articles and books were assessed for the following: (1) Community-protected area relations, which are important to understand the incentives of the community participating in conservation; (2) institutional features of the community-involved conservation practices under various names. Each paper and book was carefully read and analysed by the first two authors regarding the two analytical components. Common features of rural communities in natural resource management and their role in conservation were identified from the on-going community-protected area interactions. With the generalisation of key institutional features of the field practice regardless of the names the case used, we finally proposed a typology of community participatory continuum in the Chinese context.

The discussion is based on the information retrieved during the third phase, as well as the authors' observation of and research into the national park pilots.

\section{Results}

\subsection{Communities in Protected Areas: Features and Relations}

\subsubsection{Community-Protected Area Relations from the Perspective of Community Features}

From our literature review to both the theoretical paper and case studies, we determined that there are several prominent features of rural societies in China which impact on natural resources use. Generally, long-term human-nature interactions enabled the accumulation of ecological knowledge for sustainable use of resources $[25,26]$. Specifically, the community population mostly bound by geography and/or blood has gradually formed social norms and regulations to manage natural resources collectively [26]. Although this social bond loosened under institutional change such as the land reform and HuKou system [27], the common interest based on kinship and acquaintance society still exists as social capitals when dealing with risks outside of the land [28]. Rural communities are also risk-averse to have multiple targets in decision making, although often short-sighted for the economic benefit [28].

These features of knowledge accumulation, social bond, and collective actions, as well as risk-averse decisions, however, have been largely ignored in the early times of nature conservation. First, traditional ecological knowledge (TEK), which is a form of rational and reliable knowledge developed through generations of intimate contact by people with their land, and the rationality of adaptive land use, are not well accepted [29]. Second, people's connection to the geographic location was cut off in the change of land ownership or restriction of the bundle of rights when setting up protected areas. Common practices, such as shifting collective-owned land to state-owned land and relocation of community residents, are examples $[4,30]$. Third, the "command-control" approach inhibits the possibility of the expression of demand, and breaks the collective actions nurtured by 
human relations in common pool resource management [30]. In addition, there is less attention paid to the potential benefits a protected area can provide, such as job positions and eco-friendly branding [31].

As such, local communities often have come to face the situation that their claimed user right is contested, and their knowledge, techniques, and management regime ignored, and thus conflicts arise accordingly [32,33]. It is understandable that government-dominant conservation is a rescuing strategy to save endangered species in a short time; however, in the long run, this approach as entirely dependent on government capacity and input is not always efficient or effective, especially when conflicts hinder sustainable conservation $[30,34]$.

\subsubsection{Rethinking Community's Role in Conservation}

The community's role in conservation has gained attention in China since the 1980s, when the global conservation focus has gradually shifted from solely on biodiversity to coordinating community development [35]. A non-negligible social backdrop is structural reform of state decentralization generated by economic structural reforms. The government then welcomed the entering of international NGOs with their ideals in conservation, such as the CBC initiatives, which linked local livelihood to biodiversity conservation [36]. In terms of the features of rural communities, conservation is now clarified as a means, not an end, to balance human-nature relations in regulating resource use and benefit sharing [37].

Thus, the rural community's role stands out when these features are recognised: Community people are capable of managing their land in a reasonable way by obeying collectively defined social norms and TEK. A salient phenomenon is that the ethnic minorities, with their abundant knowledge, gained attention from decision makers [38,39]. Indeed, more conservation projects believe in collective actions to achieve environmentally compatible resource use $[40,41]$. Resource use is not prohibited but regulated to a reasonable level, with suitable direct eco-compensation and alternative livelihood to reduce livelihood risks $[40,41]$. In all, these are processes during which more responsibility, power, and benefits are transferred from the administrative body to the community [42].

The transfer of rights and obligation in conservation is accompanied by empowering the community, who can either be self-motivated or encouraged to conservation, and is leading to wider social outcomes beyond ecological and livelihood outcomes per se, such as the awakening of collective awareness to deal with individual destructive use of natural resources [42]. For example, during the empowerment, residents are more open-minded to sustainable resource use [43]; they grow aware of the economic value of ecosystem services for a better position in the negotiation of eco-compensation [44]; they are themselves educated to combine TEK and science [45]. In different social-ecological systems with unique land tenure systems and diverse ecosystems, these social outcomes can be observed in forestry management [23,46,47], wetland restoration [48], grassland management [49], and biodiversity conservation [44]. However, this empowerment is critical in theory, but not always carried out. Some projects tend to choose communities with fewer barriers to manipulate for short-term effect instead of a long-term benefit [6,50]. This partly leads to the discussion of the role of these conservation external agents, including government, NGOs, and enterprises in working with the community and the best practice models [24,42,51-53].

With the central government promotion and NGOs facilitation, many conservation projects under the name of community participation are spreading to rural China. As complementing the government top-down approach with community's bottom-up procedure is supposed to be a feasible way of improving conservation efficiency from governance reform [54], it is proposed that community participation in conservation must be a complete system that has a top-level design to guarantee and stimulate the formation of the management structure and operational regulation adaptable to specific communities [55]. However, before setting up such a complete system, we should first agree on what major governance modes are covered by community participation, other than being confused by a myriad of names affiliated to conservation initiatives and practical projects. 


\subsection{Community Participation in Protected Area Management}

\subsubsection{A New Typology of Community Participation}

Community participatory approaches to nature conservation are given various names in the Chinese literature, including but not limited to participatory management (Can Yu Shi Guan Li), community-based conservation (She $\mathrm{Qu} \mathrm{Bao} \mathrm{Hu}$ ), community co-management or condominium (She Qu Gong Guan), cooperating management (He Zuo Guan Li), and joint management (Gong Tong Guan Li). They are all used, and sometimes not differentiated, to describe community participation (She Qu Can Yu), which was proposed as opposed to the top-down governance [23,32,56,57]. It seems that this concept of community participation is accepted, if not originated, from forestry management projects in nature reserves funded by the Global Environment Fund (GEF) in the 1990s [57], and the on the ground practices with all kinds of names are gradually spreading as international and national environmental agencies become active in promoting conservation initiatives such as CBC [36].

Scholars identified some differences among the most used terms, although not for all, summarising that participatory management aims mainly at conservation targets which can be better achieved if communities help optimise social capital allocation during resource management as a social agent $[6,23,58]$, while community co-management aims at biodiversity conservation and sustainable development, and the dual goals can be realised through a long process of empowerment to the community for natural resources management $[6,24,59]$. However, the difference is not accepted unanimously, and thus interchangeable use is not uncommon. From the perspective of resource management, the protected area management agency defines its role as "housekeeper rather than master" that the community should participate in the decision making, implementation, and assessment of the protected area management plan [6]. Moreover, in terms of cooperation, there should be a balance of responsibility, power, and benefit between all the stakeholders besides the community [42]. Thus, co-management and the like in the Chinese context seems similar to the globally accepted community-based conservation $(\mathrm{CBC})[7,21]$ by making conservation and livelihood compatible. Interestingly, although CBC have several distinct phases in the global stage [19], its literal meaning in the Chinese context is frequently referred to as community initiated protected areas [24,60-62]. Therefore, it matters more to the purposes and forms of participation in conservation practice than the literal names, when we try to identify different modes of community participatory approaches.

The general concept of participation reflects the relationship between the community and the external agents, presented by Pretty (1995) in a form of a continuum depicting seven types from the highest to the lowest according to community people's right [63]. The lower levels in the continuum, represented by manipulative participation, passive participation, participation by consultation, participation for material incentives, and functional participation, are described as a means of achieving some predetermined objectives without the involvement of community people in all conservation phases. The higher level of participation continuum is depicted by interactive participation and self-mobilisation, which see participation as an end so that community people take control over local decisions and determine how available resources are used.

Accordingly, we compared definitions of common terms used in the Chinese context, as well as cases carried out in these names and their aliases, to the participation continuum. "Co-management" and "community-based conservation" generally match the higher level of participation with the former closer to interactive participation, while the latter extends to self-mobilisation. The specific concept of "participatory management" as used in different cases can refer to participation by material incentives, functional participation, and sometimes interactive participation. The detailed governance features revealed through cases are induced to general conservation modes in Section 3.2.2. 
It is also found that a dichotomy of community and external agents, be they governments or NGOs, always exists in the community participation discourse. The interaction among them signifies the governing bodies as well as stakeholder responsibilities in managing protected areas [52,64]. Some interactions reflect that community's role is becoming prominent in protected area management, although not entirely linear progress in time [65]. At first, community people are enrolled by government conservation agencies to conservation work in the government administrated protected areas $[24,47,56,66]$; then, with more external financial, technical, and experience support, usually from NGOs, conservation expanded beyond government designated protected areas to other areas worth conserving, and in both of these areas community people can join in the planning and also benefiting from conservation [24,43,52,67]; some protected areas also emerged as purely governed by the community, although the legitimacy of community-initiated conservation may also be justified by the external governmental agents $[24,60,61,68]$.

Therefore, by matching the Chinese use of different concepts to the participation continuum, and by clarifying the dichotomy of governance in practice, we identified four conservation modes according to the dominant governing body and management targets: (i) Government dominant management, aiming only at biodiversity and ecosystem conservation; (ii) community participatory management, aiming mainly at biodiversity and ecosystem conservation; (iii) community co-management, aiming at coordinating nature resources use to achieve conservation targets; (iv) community dominant management which depends on multiple-targets oriented collective action. Here a dominant role indicates the freedom of using decision-making right beside the operational responsibility. In the higher level of participation, especially the third and fourth mode proposed here, community people's participation is seen as a process in which rural residents are directly involved in designing, planning, and taking part in the conservation process from the bottom-up perspective. Conservation is not an end, but a means for the community to build the confidence and competence to fully partake in their own resource management regimes without seeking assistance from outside the community.

\subsubsection{Features of Participation Modes and Typical Cases}

Some prominent features of the three participation modes in terms of their institutional arrangements are identified (Table 1). As these features are summarised through cases regardless of the literal name of projects, a concise introduction of some typical conservation practices were used to display their core ideal of conservation pertinent to those of the three modes.

Participatory management. This mode inherits its original name and concept that was initiated from the international poverty reduction project and later accepted in ecological conservation. It can date back to the forestry project in 1988 in China, funded by the Ford Foundation in association with the Chinese Social Sciences Academy [65]. Rural community people were supposed to be the main body of forestry, with the help of the external agents to achieve sustainable forest management. Usually, community people were passively involved with a total loss of all the right of benefiting from the land, and only certain individuals enrolled in conservation activities are really participating $[6,65]$. ICDP launched by WWF in the mid-1990s was another international project which inclined towards conservation, but for which the role of villagers as conservers was not clear, and the core conservation task was lost in "development", as some research pointed out [59].

Co-management. This mode was an early if not the first manifested in the Global Environment Fund (GEF) funded Nature Reserve Management Programme (NRMP) in 1995 [69]. Promoted by the World Bank and the National Forestry Bureau, "co-management" was literally used and defined as shared management of natural resources by the community and the nature reserve, featured by cooperatively making a resource management plan and the community assisting in biodiversity conservation work. Cases such as in Wolong, Changbaishan, Jiuzhaigou, etc., have all demonstrated that co-management was efficient in balancing the public and private interests in the government-dominant protected areas by matching the rights and responsibilities of stakeholders [70,71]. In some ICDPs, WWF focused on improving the sustainability of the project by taking in the enterprise to maintain a money 
flow in the production chain, which is friendly to biodiversity and profitable to the community [40]. In addition, growing attention was paid to empower the community to participate in decision making, planning, and benefit sharing [41,72], as well as to raise their awareness of the relationship between resource use and ecosystem integrity [49].

Community-dominant management. This mode developed especially fast in the area outside of the government designated and managed protected areas, with or without external agents $[62,64,68]$. Multiple targets are included in the protected area management besides clear ecological conservation, such as environmental education, ecological community construction, and community empowerment [6].

Several agents are active in guiding community-dominant management. They have similar roles as US land trust to steward land for conservation purposes, but are different, as they cannot acquire land due to the Chinese land ownership systems. The conservation stewards programme (CSP) initiated by the Conservation International (CI) was introduced to China in 2005 and executed by Shanshui Nature Reserve Center and Global Environmental Institute (GEI), mostly in the west and southwest China $[52,67,73]$. Usually, a certain area of ecologically valuable land in or around existent nature reserves is entrusted to the NGOs to be managed in the way of a nature reserve. NGOs were mainly engaged in cooperating with local governments and communities to facilitate suitable economic incentives under land tenure constraints and conservation targets. Similarly, entrusted conservation is another form initiated by The Nature Conservation (TNC) in Sichuan [74]. The Old Creek Nature Reserve is one with the land use right transferred to the Sichuan Paradise Foundation for 50 years from the county government facilitated by TNC. The land is entrusted to the third party, but the daily management responsibility lies on the community.

There is also a community-conserved area without external agents when setting up. These areas are usually good in natural conditions in terms of biodiversity and ecosystem services, benefiting both the local people and beyond [27]. It is featured by multiple targets as not only a protected area, but also an economic area evolving from human-nature interaction in which certain institutions and traditional cultures apply to natural resources management. These areas are gradually recognised as, or promoted to, a complement of top-down designated protected areas by the government. The nature mini-reserve managed by the local community is one type that was initiated and approved by the forestry department at the county level in 1992 in Jiangxi, and is well developed in other east provinces such as Fujian and Guangdong $[6,60,61,75]$. NGOs such as Shanshui Nature Reserve Center have also coordinated between government and communities in the institution and capacity building, and help wider social participation into the communities' public welfare development [52]. The sacred area was usually managed by communities with certain religious beliefs. Abundant ecological knowledge and experience accumulated during natural resources management are contributing to biodiversity conservation. As in the three-river-source area of Qinghai province, these areas are recognised by the government, so it is possible for a community to get more external resources and to popularise their experience [62].

\section{Discussion}

The review of features of the communities and their changing roles in conservation has confirmed that, although the participatory concept may be borrowed, it has gradually adapted to the Chinese context by respecting people's connection to their geographic location, to their peers and to their culture, through conservation practices. These on the ground practices may or may not function as what is pre-defined in the initiatives or projects. However, precisely because of this mismatch between concept and practice, we can clarify confusion about pre-defined but randomly used concepts or about various initiatives from the actual participation situation revealed in practice, and summarise practices up to concise modes. In the discussion, we further put forward some features in practices that matter to the success of community participation and may also contribute to the current national park practice. 


\subsection{Community Participation: Maintaining the Right to Benefit from Conservation}

The historical change of PA-people relation in China has revealed a number of "rules of thumb" in community participation in conservation:

(i) Admit rural people as legitimate resource users in the ecological system. Successful conservation sees the human aspects of the ecological problem, that people depend on nature for livelihood. In China, access to natural resources is defined by land ownership and use right. Thus, the first and foremost institutional incentive to conservation is the stability and flexibility of the land tenure system. Stability basically ensures collectively owned land and/or land contracted to households won't be expropriated during protected area designation. Flexibility indicates the legal transfer of contract rights in the first place. Recently, the concept of property rights as a bundle is becoming critical. Bundle-of-rights is used to explain separation of certain profit right from the land use rights, so that community people can avoid a total loss of land use right, but still benefit from approved land management, such as in conservation easement [24,28]. Thus, as legitimate resource users holding their "certificate of the right to rural land contractual management", rural people should benefit from natural resources if their activities are compatible with the conservation targets. This idea has been accepted to the current national park pilots $[74,76]$.

(ii) Apply various forms of compensation to minimise damage to the social system. Constraints to resource use and loss of culture are both confirmed to negatively impact rural people's attitude and participation in conservation $[24,28,64,68,77]$. By contrast, economic benefits and fair benefit sharing did the opposite $[24,28,36,52,77]$. Cases have proven that many ways other than monetary compensation facilitate the trust building between the community and external agents in an adaptive way in that people's relation to nature is largely reserved, such as to marketize agricultural products and handicrafts $[27,36,43,52]$, to facilitate provision of ecotourism service $[24,39,42,56]$, and to hire herders as rangers in the newly built national parks $[24,64]$. These approaches develop conservation-compatible livelihoods that keep people in the field to maintain their culture, and also guarantee long-term benefits to crack down the externality issue in conservation.

(iii) Rediscover knowledge for conservation through TEK. TEK is an integrated system of knowledge, belief, and practice form during the co-evolvement of humans and nature. In many minority-dwelt areas and other rural counties in China, moral judgment and social norms regulate people's behaviour towards sustainable resource management $[24,46,52,68]$. This self-organised collective action often delivers conservation outcomes which can be traced back to certain TEK that needs to be interpreted for ecological mechanisms. This interpretation process is knowledge co-productive with a combination of modern ecological sciences and traditional knowledge [28]. This new knowledge is applicable to conservation practices such as ecosystem monitoring and evaluation [24,52], regional planning [46,78], nature education [24,29,41], etc. A prominent aspect of TEK is that social restraints act essentially in regulating resource use and they are initiated from, and feedback to, coordination, cooperation, rule-making, and enforcement [78], which all matter to adaptive protected area management.

These rules of thumb suggest the necessity of ensuring sustainable benefits, not only from providing a wide array of income generation tools, but also facilitating community empowerment. The benefit could only be generated and sustained when community people are themselves the plan makers and action executers at the same time, such as in the development plan of ecotourism $[27,28,42,79]$. Participation theory may have been imported, but the practice in conservation in China can date back as early as the 1960s, when the ethnic minority people contributed knowledge and labour for the boundary demarcation of panda reserves [80], and the level of participation has escalated since. 
International NGOs have since channelled prominent energy and resources toward this empowerment by working with local NGOs. They actually smoothed the implementation of some national policies, such as a ban on logging, in rural communities by helping secure livelihoods from sustainable forms of income generation $[26,40,46]$. More importantly, they have facilitated the community's social restraints restoration by implementing conservation practices in which social norms rediscovered from TEK must take effect to form virtuous value cycles. For those who are self-motivated to conservation, NGOs can also coordinate the community and government in protected area demarcation and resource management rules, and the community is thus empowered with confidence, skill, and the ability to generate conservation outcomes by optimising natural resources management for long-term human well-being [81].

In the end, the paramount goal of community empowerment is to generate collective actions to manage resources under certain rules towards conservation targets [5,82]. Collective actions in protected area management involve many aspects including planning, human resources management, benefit sharing, supervision, reward and punishment, etc. [6]. However, as the mentioned above, social restraints are weakening and gone with TEK under the market-driven exploration of resources, and community empowerment needs to reawaken the worldview of humans-as-part-of-nature to balance short-term economic benefits and long-term cultural and ecological benefits. The devices to reach the balance are hopefully in the "rules of thumbs". However, although reports sing high praise for NGOs' enthusiasm and deliverables, few serious studies observed the empowerment and evaluated the outcomes [79]. 
Table 1. Community participatory conservation modes and features.

\begin{tabular}{|c|c|c|c|c|c|c|c|c|c|}
\hline Mode & Area & Targets & $\begin{array}{l}\text { Governing } \\
\text { Body }\end{array}$ & Coordinator & Supervisor & $\begin{array}{l}\text { Financial } \\
\text { Provider }\end{array}$ & Incentives & Guarantee & Main Sources \\
\hline $\begin{array}{l}\text { Community } \\
\text { participatory } \\
\text { management }\end{array}$ & Existing PAs & Biodiversity & Government & $\begin{array}{l}\text { None/Non- } \\
\text { governmental } \\
\text { organisations } \\
\text { (NGOs) }\end{array}$ & Government & $\begin{array}{l}\text { Government } \\
\text { sectors; NGOs; } \\
\text { profiting } \\
\text { agencies }\end{array}$ & $\begin{array}{c}\text { Conservation job } \\
\text { position; livelihood } \\
\text { development; } \\
\text { eco-compensation; public } \\
\text { welfare provision }\end{array}$ & $\begin{array}{l}\text { PA management } \\
\text { regulations; } \\
\text { agreement; village } \\
\text { rules and regulations }\end{array}$ & {$[6,23,46-48,58,59,65]$} \\
\hline $\begin{array}{l}\text { Community } \\
\text { Co-management }\end{array}$ & Existing PAs & $\begin{array}{l}\text { Biodiversity; } \\
\text { natural } \\
\text { resources use }\end{array}$ & $\begin{array}{l}\text { Government } \\
\text { \& Community }\end{array}$ & NGOs & Government & $\begin{array}{l}\text { NGO; } \\
\text { government } \\
\text { sectors; }\end{array}$ & $\begin{array}{l}\text { Conservation job } \\
\text { position; alternative } \\
\text { livelihood; alternative } \\
\text { energy supply; land } \\
\text { property right of } \\
\text { (operation, benefit, } \\
\text { transfer, etc.) }\end{array}$ & $\begin{array}{l}\text { PA management } \\
\text { regulations; } \\
\text { agreement; village } \\
\text { rules and regulations }\end{array}$ & $\begin{array}{c}{[40,41,44,49,51,56,66} \\
69-72,77,83]\end{array}$ \\
\hline $\begin{array}{l}\text { Community } \\
\text { dominant } \\
\text { management }\end{array}$ & $\begin{array}{l}\text { Existing \& } \\
\text { new PAs }\end{array}$ & $\begin{array}{l}\text { Biodiversity; } \\
\text { natural resource } \\
\text { use; landscape; } \\
\text { culture, etc }\end{array}$ & Community & $\begin{array}{l}\text { NGOs/ } \\
\text { Government/ } \\
\text { None }\end{array}$ & $\begin{array}{l}\text { Community/ } \\
\text { Government/ } \\
\text { Public }\end{array}$ & $\begin{array}{l}\text { Community; } \\
\text { NGOs; } \\
\text { government }\end{array}$ & $\begin{array}{l}\text { Self-awareness of natural } \\
\text { resource value; religious } \\
\text { belief; moral obligation }\end{array}$ & $\begin{array}{l}\text { Village rules and } \\
\text { regulations; moral } \\
\text { obligation and } \\
\text { religious belief; } \\
\text { government-approved } \\
\text { management rules }\end{array}$ & $\begin{array}{c}{[24,52,60-62,64,67,68} \\
73-75]\end{array}$ \\
\hline
\end{tabular}




\subsection{Implications for the National Park Management and PA System Reform}

Current China national parks are still pilots enjoying a privileged position as a testing ground for institutional innovation of conservation. In the Overall Plan for Establishment of A National Park System, coordinated community development is one of several reform targets. Three pathways are encouraged in the Overall Plan, namely the co-management (she qu gong guan) concerning rural people and gateway communities, the eco-compensation in the monetary form and from job positions of monitoring and education, and social participation (she hui can yu) referring to multiple social agents engaged in the franchising, volunteering, and supervising, etc. The role of local communities is gaining more attention as national parks become a mainstay in the protected area system (with the other types of nature reserve and nature park), however, the addressed pathways are not entirely new, but need optimisation through legislation, planning, practice, and supervision [24]. Accordingly, we address some prominent issues as follows based on the research and our experience.

Improvement of the legal system is a priority. Observation of conservation practice in China is intriguing because innovation often precedes theories. One example is the initiation of the Civil Protected Area Alliance. It consists of 23 international and national NGOs and 39 protected areas, which, if defined according to our research, are mainly co-management and community-dominant protected areas. However, the current literature on community participation reveals a significant lack of attention to these on the ground practices as are reported by the Alliance. Because of this shortage, this review research may have missed some features in certain modes, such as individual and commercial participation. Flexible land tenure and clearly defined property (bundle) rights played a critical role in facilitating these protected areas, which are ambitiously marching to the $1 \%$ of the territory conservation target with a current $7630.42 \mathrm{~km}^{2}$ (i.e., $7.92 \%$ of the target) [83]. They are contributing to the conservation network and proved a success in community empowerment in many cases, however, this community-dominant conservation does not own a legal position in the protected area system, nor the Conservation Stewards Program (CSP) contract and alike are protected by law. Similarly, conservation easements have been practised in the Qianjiangyuan and Wuyishan national park pilots to the collectively-owned forest land without a legal complement or explanation to the current article of easement in the Property Law [76]. In fact, other mechanisms concerning community participation may all need a full update of laws, such as the franchising system.

A fair benefit sharing system must be maintained or optimised. Most of the national parks are an integration of previous nature reserves, forest parks, wetlands or so, where conflicts between communities and the protected area, if any, are inherited to and must be tackled by the new national park [4]. Typical conflicts arose from unfair benefit sharing, especially in the tourism industry, because ecotourism as an environment-friendly livelihood is emulated in many nature reserves by taking Wolong Panda reserve as a model [80], and because many scenic areas for sightseeing are now a part of national parks [4,78]. Pilots like Wuyishan, Shennongjia, Pudacuo, Giant panda, etc. all have attracted some research into the benefit sharing among stakeholders. Personal observations reveal that eco-tourism can fully benefit local communities if applied based on science-oriented plan and community participation, however, it happens that investment from outside did not payback to local people or only benefit a certain amount of people for renting their land, and gateway communities enjoy a lucrative profit, while remote communities close to the national park gain nothing. Franchising is proposed to encourage local people into the business, but the previous monopoly of tourism companies has yet to cease.

Multiple compensation methods should adapt to different social-ecological systems. Unique social-ecological systems exist from the perspective of the natural resource use of local communities. Evidence abounds that economic compensation is incentives to community participation. However, many community residents are only passively affected by conservation to accept some top-down blanket eco-compensation, or to take some jobs that only aim at conservation outcomes without catering to people's development needs $[77,79]$. National parks bring new challenges to the efficiency of monetary compensation as well. For example, herders at the junction of Qinghai and Gansu 
province in the Qilianshan national park used to get different amounts of eco-compensation for grazing prohibition and a grassland-livestock balance, however, now herders in Gansu are seeking higher standards to match their neighbours. Human-wildlife conflict is another issue. In Sanjiangyuan, Qilianshan, Shennongjia National Parks, etc., the one-off compensation for lost herds is blamed for its economic expediency that resulted in vicious human-nature relations, such as retaliatory hunting as told. Some pilots, such as Sanjiangyuan, are seeking multiple ways of raising money, as well as diversifying compensation forms. Based on the local resource use, herders and farmers are hired as rangers to officially join surveying, patrolling, and monitoring of ecosystems [64]. Taking part in nature education is also facilitated to give full play to local people's knowledge. Thus, a full compensation system should be complex to match the human-nature relations embedded in each social-ecological system, so that the local community can actively generate sustainable cash flow, apart from passively fed by subsidies.

Community participation is within a larger discourse of social participation. The experience of community participation indicated that NGOs are bringing social connections as well as financial resources to the local community in setting up production chains, training nature guides, negotiating trusted contracts, etc. They help local people reach out to the outside while keeping benefits inside through valuing their knowledge and practice, which do not have obvious economic values before. Challenge then arises in the national park era, or actually never fades that it is essential but difficult to identify the common interest of conservation between the community and its partners, who are growing when the social network expands $[28,64,84]$. On the one hand, the concept of social participation helps clarify possible cooperation between local community and other social agents including NGOs, tourists, volunteers, scientists, local government, and authorised certificate holders, etc., thus providing more opportunities to benefit from a common interest. On the other hand, community empowerment becomes even more important as community people need the ability to identify conservation issues and cooperate with outside agents, since they are the only insiders.

\section{Conclusions}

Community participation in conservation is well discussed in the global conservation context, but a summary of its modes adaptive to the Chinese context is yet to come, or at least not systematically presented. This is a missed opportunity to learn from field experience to improve the effectiveness of community participation in conservation. This research thus aims to fill this gap between practices and theory by identifying community participation modes and providing further suggestions to conservation practices.

Three community participation modes are reduced from practical cases, and generally fit the participatory continuum with differences in the relations between the community and the external agents, management targets, and incentives. Such a clear-cut mode definition provides guidance for analysing various conservation projects without the confusion of naming. Both of the rural development and nature conservation issues have priority in the institutional reform of China. The conservation experience has confirmed that coordinating them is necessary and possible as community participation in conservation can be an empowerment process to maintain the human-nature relations while achieving multiple targets. Communities' role in conservation has changed as conservation is becoming a means, not an end, complying with rural people's demand for sustainable resource use and fair benefit sharing.

Thus, several implications for China National Parks are drawn from the community participation experience in China. It proved that the legitimate land tenure with which economic benefit and cultural traditions affiliate is the major concern of the local community. Thus, a long-term benefit is better secured by a stable and flexible land tenure system that treats the land property as a bundle for the community to have the right to benefit. The right to benefit, however, is to be secured through an institutional change in the national park era, mainly with improvement in the legislation and optimisation in benefit sharing and compensation. In the end, community participation is evolving 
with social participation in which linkage between local people and outside agents is getting stronger, and community empowerment per se is key to maintain the linkage for a common conservation interest.

Author Contributions: Conceptualization, S.H.; methodology, S.H. and L.Y.; literature collection, L.Y. and S.H.; literature review and data analysis, S.H. and L.Y.; writing-original draft preparation, L.Y. and S.H.; writing_-review and editing, S.H. and Q.M.; project administration, Q.M.; funding acquisition, Q.M. and S.H. All authors have read and agreed to the published version of the manuscript.

Funding: This research was funded by China National Key Research and Development Plan (2017YFC0506404) and the Start-up Programme for Junior Researcher of the Institute of Geographic Sciences and Natural Resources Research.

Acknowledgments: The authors would like to thank all the interviewees from NGOs, protected area management agencies, local government, and rural communities, who contributed their time and knowledge to this study.

Conflicts of Interest: The authors declare no conflict of interest. The funders had no role in the design of the study; in the collection, analyses, or interpretation of data; in the writing of the manuscript, or in the decision to publish the results.

\section{References}

1. Mansuri, G.; Rao, V. Community-based and driven development: Acritical review. World Bank Res. Obs. 2004, 19, 1-39. [CrossRef]

2. Lele, S.; Wilshusen, P.; Brockington, D.; Seidler, R.; Bawa, K. Beyond exclusion: Alternative approaches to biodiversity conservation in the developing tropics. Curr. Opin. Environ. Sustain. 2010, 2, 94-100. [CrossRef]

3. Brooks, J.; Waylen, K.A.; Mulder, M.B. Assessing community-based conservation projects: A systematic review and multilevel analysis of attitudinal, behavioral, ecological, and economic outcomes. Environ. Evid. 2013, 2, 2. [CrossRef]

4. He, S.; Su, Y.; Wang, L.; Gallagher, L.; Cheng, H. Taking an ecosystem services approach for a new national park system in China. Resour. Conserv. Recycl. 2018, 137, 136-144. [CrossRef]

5. Ostrom, E. Governing the Commons: The Evolution of Institutions for Collective Action; Cambridge University Press: New York, NY, USA, 1990.

6. Li, S. Management and Outsides Interventions of Community-Conserved Areas; Peking University Press: Beijing, China, 2014.

7. Selfa, T.; Endter-Wada, J. The politics of community-based conservation in natural resource management: A focus for international comparative analysis. Environ. Plan. 2008, A40, 948-965. [CrossRef]

8. Margereum, R.D. Overcoming locally based constraints. Soc. Nat. Resour. 2007, 20, 135-152. [CrossRef]

9. Lurie, S.; Hibbard, M. Community-based natural resource management: Ideals and realities for Oregon Watershed Councils. Soc. Nat. Resour. 2008, 21, 430-440. [CrossRef]

10. Selin, S.; Chavez, D. Developing a collaborative model for environmental planning and management. Environ. Manag. 1995, 19, 189-195. [CrossRef]

11. Keen, M.; Mahanty, S. Learning in sustainable natural resource management: Challenges and opportunities in the pacific. Soc. Nat. Resour. 2006, 19, 497-513. [CrossRef]

12. Stringer, L.C.; Dougill, A.J.; Fraser, E.; Hubacek, K.; Prell, C.; Reed, M.S. Unpacking "participation" in the adaptive management of social-ecological systems: A critical review. Ecol. Soc. 2010, 11, 39. [CrossRef]

13. Calfukura, E. Governance, land and distribution: A discussion on the political economy of community-based conservation. Ecol. Econ. 2018, 145, 18-26. [CrossRef]

14. Soeftestad, L.T. Community-Based Nature Resource Management: Knowledge Management and Knowledge Sharing in the Age of Globalisation. CBNRM Net Papers, no. 1, 2001. Available online: https:/www.tnrf.org/ en/node/5186?lang=en (accessed on 21 December 2018).

15. Wells, M.; Brandon, K. People and Parks: Linking Protected Area Management with Local Communities; The World Bank: Washington, DC, USA, 1992.

16. FAO. How Forests can Reduce Poverty, Policy Brief prepared for Policy Makers, Forest Policy and Institution Service; FAO: Rome, Italy, 2001.

17. The World National Parks Congress. Recommendations of the World National Parks Congress. Envtl. Pol'y E L. 1983, 10, 63-68. 
18. Salafsky, N.; Wollenberg, E. Linking livelihoods and conservation: A conceptual framework and scale for assessing the integration of human needs and biodiversity. World Dev. 2000, 28, 1421-1438. [CrossRef]

19. Berkes, F. Community-Based Conservation in a Globalized World. Proc. Natl. Acad. Sci. USA 2007, 104, 15188-15193. [CrossRef]

20. Gómez-Baggethun, E.; Muradian, R. In markets we trust? Setting the boundaries of market-based instruments in ecosystem services governance. Ecol. Econ. 2015, 117, 217-224. [CrossRef]

21. Nilsson, D.; Baxter, G.; Butler, J.; McAlpine, C. How do community-based conservation programs in developing countries change human behaviour? A realist synthesis. Biol. Conserv. 2016, 200, 93-103. [CrossRef]

22. Fang, J.; Ma, X.; Gao, Y. History and development of community-based biological conservation: Implications for China. Science (KEXUE) 2018, 70, 19-22. (In Chinese)

23. Lai, Q. Community participation in the management of nature reserves: Experiences and lessons from China. Unasylva 2003, 54, 51-57.

24. Liao, L.; Zhao, Z.; Yang, R. Model analysis of community participation in protection of China's protected areas based on a comparative study of six cases. Chin. Landsc. Arch. 2017, 33, 30-33. (In Chinese)

25. Fu, X. Study of the economic development of communities in the nature reserves in Western China. Fut. Dev. 2005, 5, 51-53+50. (In Chinese)

26. Zhang, X. Research on the China Nature Reserves and the Community Management Mode. Ph.D. Thesis, Northwest Agriculture and Forestry University, Xianyang, China, 2012. (In Chinese).

27. Li, S. Community conserved area and new rural construction. J. Southwest Univ. Natly Hum. Soc. Sci. 2009, 30, 40-44. (In Chinese)

28. He, S.; Su, Y.; Wang, L.; Cheng, H. Developing a social context analysis tool to facilitate communities' conservation behaviour in protected areas: An experiment in the Wuyishan National Park Pilot. Acta Ecol. Sin. 2019, 39, 3861-3870. (In Chinese)

29. $\mathrm{Xu}, \mathrm{T}$. Inspiration form the tendency of admitting community participation in World Heritage conservation. Des. Commun. 2016, 3, 26-30. (In Chinese)

30. Xu, Q.; Hu, W.; Wang, X. An approach to sustainable management pattern of China's Nature Reserves-taking management pattern of London's Nature Reserves for reference. Urban Environ. Urban Ecol. 2001, 5, $20-22$. (In Chinese)

31. Chen, X.; Jin, X.; Su, Y. The initiative and experiences of the national park management system reform in france and its enlightenment to China. Environ. Prot. 2017, 45, 56-63. (In Chinese)

32. Cao, Y.; Zhang, D. Development of community co-management in the nature reserves in the construction of a harmonious society. J. Anhui Agric. Sci. 2008, 34, 742-745-15. (In Chinese)

33. Li, Y. Improving community co-management for biodiversity conservation and rural economic development. Guangxi For. Sci. 2004, 33, 54-56. (In Chinese)

34. He, Q.; Li, X.; Yin, Z.; Li, M.; Zhou, W. Investigation of fish resources in Jietouxiaojiang and effectiveness of community conservation in Tengchong, Yunan. Sichuan J. Zool. 2014, 33, 134-138. (In Chinese)

35. Jones, S. A political ecology of wildlife conservation in Africa. Rev. Afr. Polit. Econ. 2006, 33, 483-495. [CrossRef]

36. Wang, C.; Wen, Y.; Hu, C.; Si, K. Research progress on harmonious development of Nature Reserves and surrounding communities. Issues For. Econ. 2010, 30, 486-492. (In Chinese)

37. Deng, W. The discussion on the community development under the effective management of natural reserves. For. Soc. 2005, 1, 1-6. (In Chinese)

38. Zhao, Y. Community- oriented Nature Conservation. For. Econ. 2006, 11, 69-73. (In Chinese)

39. Liu, J.; Miao, H.; Ouyang, Z.; Li, X. Typical patterns on the relationships between protected areas and local communities. Chin. J. Ecol. 2008, 9, 1612-1619. (In Chinese)

40. Wang, J.; Dong, S.; Zhang, Z.; Ma, K.; Zheng, S. Community united protection project-a kind of new community forest management mode. J. Shaanxi Normal Univ. Nat. Sci. Ed. 2006, S1, 233-237. (In Chinese)

41. Luo, P.; Qin, Z. Community participation models of geological heritage resource conservation and development: A case of Huayingshan grand canyon geo-park. Geogr. Res. 2013, 32, 952-964.

42. Liu, D.; Shi, D. Analysis on community condominium of nature protection areas. Prob. For. Econ. 2003, 23, 53-55. (In Chinese) 
43. Tang, Y.; Dong, W.; Zhao, M. A study of countermeasures for community condominium of qiongzhuea tumidinoda biodiversity conservation area. World Bamboo Rattan 2009, 7, 22-25. (In Chinese)

44. Zhao, J. Model innovation on local villagers condominium and the protection of biodiversity-taking Wuliangshan national nature reserve as an example. J. Yunnan Univ. Financ. Econ. 2007, 5, 18-23. (In Chinese)

45. Chen, S.; Hu, C. Strategic analysis of community conservation education in the nature reserves-a case of Taibai Mountain Nature Reserve. Prot. For. Sci. Technol. 2011, 3, 76-78. (In Chinese)

46. Wang, Q.; Zhang, W. Preliminary study on communities participation protection of natural forest in state forest area. J. Gansu For. Sci. Technol. 2007, 32, 37-40. (In Chinese)

47. Chen, Z.; Yang, M.; Yu, C.; Wen, Q. Research on community co-management of Jiaozishan national nature reserve. For. Inventory Plann. 2018, 43, 59-62.

48. Ma, M.; Mao, Z. Wetland ecological conservation under the perspective of community participation-A case of Yunnan Dashanbao wetland of international importance. J. Anhui Agric. Sci. 2016, 44, 229-230. (In Chinese)

49. Wang, H.; Li, X. Application of participatory community condominium in biodiversity conservation in Tibetan areas-Taking Makehe community of Banma Couty in the Yangtze River basin as an example. J. Qinghai Univ. Nat. Sci. Ed. 2015, 33, 92-97.

50. Tang, Y.; Luo, X. The Indigenization of community-based co-management of the natural resources in China. J. Guizhou Univ. Soc. Sci. 2012, 30, 97-101.

51. Huang, M.; Hong, S. Combining nature conservation with village development-An analysis of Caohai Nature Reserve cooperation programme. Guizhou Environ. Prot. Sci. Technol. 1997, 3, 46-48. (In Chinese)

52. Li, X.; Bai, J. Study on the reasonable role of interest groups in the agreement protection projects: Based on exploring the project of agreement protection in Liziba. Ecol. Econ. 2012, 11, 166-170. (In Chinese)

53. Liu, X.; Zhang, Y. A review on the nature reserve co-management theory in China. Econ. Res. Guide 2011, 122, 193-195.

54. Yan, S.; Sun, M.; Chen, D. Research on community participation system of national park under the perspective of collective choice theory. J. Hum. Settl. W. China 2016, 31, 68-72. (In Chinese)

55. Zhang, X. Implementing community co-management to facilitate biodiversity conservation. For. Econ. 2000, 4, 29-32. (In Chinese)

56. Huang, X.; Chen, Z. Feedback from the community co-management mechanism in Wuyi Mountain National Nature Reserve. Tianjin Agric. Sci. 2015, 21, 140-143. (In Chinese)

57. Huang, W.; Yang, D.; Zhang, G. A review of progress of community involvement in nature reserve management in China. Hunan For. Sci. Technol. 2006, 31, 46-48.

58. Liang, Q.; He, S. Community co-management exploration involving in commercial mechanism - Project of sustainable apiculture based on conservation in and around Foping NR. J. Shaanxi Norm. Univ. Nat. Sci. Ed. 2006, 34, 228-232. (In Chinese)

59. Xu, J.; Chen, L.; Lv, Y.; Fu, B. Harmonization of protected areas management and local development: Methods, practices and lessons. Chin. J. Ecol. 2005, 1, 102-107. (In Chinese)

60. Lin, H. Nature mini-reserves in Fuqing, Fujian: Current status and development measures. Agric. Technol 2017, 37, 70-71. (In Chinese)

61. Li, G. Feature analysis of Nature mini-reserves in Jianou, Fujian. For. Prospect Des. 2017, 37, 90-93. (In Chinese)

62. Shen, X.; Lu, Z.; Li, S.; Chen, N. Tibetan sacred sites: Understanding the traditional management system and its role in modern conservation. Ecol. Soc. 2012, 17, 13. [CrossRef]

63. Pretty, J.N. Participatory learning for sustainable agriculture. World Dev. 1995, 23, 1247-1263. [CrossRef]

64. Zhao, X.; Zhu, Z.; Lv, Z.; Xiao, L.; Mei, S.; Wang, H. An observation to the new initiative of community conservation guard posts in the pilot Three-River-Source National Park. Biodivers. Sci. 2018, 26, 210-216. [CrossRef]

65. Ni, J. Community-based Conservation From Case Perspective; Peking University Press: Beijing, China, 2014.

66. Li, R. Coordinated development of community and joint conservation in the Wuyishan Nature Reserve. For. Econ. 2001, 12, 55-57. (In Chinese)

67. Zhang, S.; Wang, J. Community co-management situation in the Gaoligong Mountain Nature Reserve. Xiang Cun Ke Ji 2008, 1, 101-102. (In Chinese)

68. An, F. A review on the community development based on nature mini-reserves. Public Commun. Sci. Technol. 2010, 9, 25+19. (In Chinese) 
69. Wen, Y. Community Co-Management in the Nature Reserves; China Forestry Press: Beijing, China, 2002.

70. Zhang, H.; Yang, X.; Li, S. Inspiration of community co-management for developing ecotourism in natural preservation zone. Hum. Geogr. 2005, 3, 120-106+66. (In Chinese)

71. Liu, Y.; Tang, Y. On community condominium model of national nature reserve in the Taibai Mountain of Shaanxi. J. Northwest For. Univ. 2005, 20, 184-188. (In Chinese)

72. Lang, Z.; Zhang, Y.; Liu, H.; Gong, H. Study of biodiversity conservation in Ailao Mountains StateNature reserve based on community co-management. J. Green Sci. Technol. 2014, 7, 6-9. (In Chinese)

73. Li, S. On the Conservation Stewardship in the eco-compensation. Rural Econ. 2007, 8, 26-28. (In Chinese)

74. Yang, Y.; Huang, K.; Huang, B. Research progress of public welfare protected land under the background of national park construction. Chin. J. Environ. Manag. 2019, 11, 72-76. (In Chinese)

75. Chen, X. Protection and management status and countermeasures of nature reserves in Yanping District. Anhui Agric. Sci. Bull. 2018, 24, 113-116. (In Chinese)

76. Wei, Y.; He, S.; Lei, G.; Su, Y. Establishing conservation easement system to promote unified management of China's National Parks: US-Based Experience. J. Beijing For. Univ. Soc. Sci. 2019, 18, 70-79. (In Chinese)

77. Zhang, X.; Wang, Z.; Li, X. Analysis on limiting factors of co-management model in Chinese Nature Reserves. Chin. Agric. Sci. Bull. 2007, 5, 396-399. (In Chinese)

78. He, S.; Su, Y.; Min, Q. Boundary, zoning, and land use management of the China National Parks: Learning from nature reserves and scenic areas. Acta Ecol. Sin. 2019, 39, 1318-1329. (In Chinese)

79. Pan, Z.; Liang, E.; Wu, Y.; Lin, Y.; Cao, T. Community empowerment: An effective way to realize the community's involvement in tourism development. Tour. Forum 2014, 7, 43-49. (In Chinese)

80. Songster, E.E. Panda Nation: The Construction and Conservation of China's Modern Icon; Oxford University Press: New York, NY, USA, 2018.

81. Kim, S.; Li, G.; Son, Y. The contribution of traditional ecological knowledge and practices to forest management: The case of Northeast Asia. Forestry 2017, 8, 496. [CrossRef]

82. Zuo, T.; Gou, T. Research on cooperating management (condominium) of nature reserves. For. Econ. 2005, 4, 49-52. (In Chinese)

83. Jin, T. Observation on the Development of Social Public Welfare Protected Area in China 2017. Available online: http://civilpa.org.cn/portal/article/index/id/141.html (accessed on 16 March 2020).

84. He, S.; Su, Y.; Wang, L.; Cheng, H. Identification and assessment of ecosystem services for protected area planning: A case in rural communities of Wuyishan national park pilot. Ecosyst. Serv. 2018, 31, 169-180. [CrossRef]

(C) 2020 by the authors. Licensee MDPI, Basel, Switzerland. This article is an open access article distributed under the terms and conditions of the Creative Commons Attribution (CC BY) license (http://creativecommons.org/licenses/by/4.0/). 